Jurnal Media Pertanian Vol. 2 No. 2 Tahun 2017 Hal. 85 - 91

Media Komunikasi Hasil Penelitian dan Review Literatur Bidang Ilmu Agronomi

ISSN print $2503-1279$

ISSN online $2581-1606$

\title{
PENGGUNAAN LARUTAN KIMIA DALAM PEMATAHAN DORMANSI BENIH KOPI LIBERIKA
}

\author{
Yulistiati Nengsih \\ Program Studi Agroteknologi, Fakultas Pertanian Universitas Batanghari \\ J1. Slamet Riyadi-Broni-Jambi, 36122 Telp. +62074160103 \\ email : nyulistiati@yahom.com
}

\begin{abstract}
In fact, coffee cultivation should be met one of the constraints as seeds dormancy due to the harsh skin condition of the seed so that water and needed in the germination process can not get into the seed. To soften the hard skin of coffee beans can be done with an easy and effective way by soaking the seeds in the solution. This study aims to find out which solution is appropriate in breaking dormancy and increasing the viability and vigor of liberative coffee seed. The experiment was conducted by soaking the coffee seeds using $\mathrm{KNO}_{3}$ solution at 0,5\% concentration and soaking in water treatment $\left(\mathrm{H}_{2} \mathrm{O}\right)$ for 24 hours. Soaking the coffee seeds in $\mathrm{H}_{2} \mathrm{SO}_{4}$ solution with $20 \%$ concentration for 30 minutes and soaking the coffee seeds in coconut water concentration 50\% for 4 hours.

Observed parameters: Potential Viability Parameters, Growth Rate Index, Sprout Height (cm), Dry Root Weight (mg), and Sprout Dry Weight (mg). To observe the observed treatment, all the final data from the observed results were analyzed variance, when different treatments were followed by the Duncan test. The results showed the use of chemical solutions $\mathrm{KNO}_{3}$ and $\mathrm{H}_{2} \mathrm{SO}_{4}$ able to show the viability of the seeds of good coffee liberika.
\end{abstract}

Keywords: dormancy, germination process and growth rate index

\begin{abstract}
Abstrak
Dalam praktek pembudidayaan kopi dihadapkan pada kendala biji yang mengalami dormansi karena keadaan kulit biji yang keras sehingga air dan udara yang dibutuhkan dalam proses perkecambahan tidak dapat masuk ke dalam biji. Untuk melunakkan kulit biji kopi yang keras dapat dilakukan dengan cara mudah dan effektif yaitu dengan melakukan perendaman benih dalam larutan. Penelitian ini bertujuan untuk mengetahui larutan mana yang tepat dalam mematahkan dormansi serta meningkatkan viabilitas dan vigor benih kopi liberika. Pelaksanaan penelitian dilakukan dengan cara merendam benih kopi menggunakan larutan $\mathrm{KNO}_{3}$ pada konsentrasi $0,5 \%$ dan perlakuan perendaman dalam air biasa $\left(\mathrm{H}_{2} \mathrm{O}\right)$ selama 24 jam. Perendaman benih kopi dalam larutan $\mathrm{H}_{2} \mathrm{SO}_{4}$ dengan konsentrasi $20 \%$ selama 30 menit dan perendaman benih kopi dalam air kelapa konsentrasi 50\% selama 4 jam. Peubah yang diamati :Parameter Viabilitas Potensial, Indeks Kecepatan Berkecambah, Tinggi Kecambah (cm), Berat Kering Akar (mg), dan Berat Kering Kecambah (mg). Untuk melihat perlakuan yang diamati, semua data akhir dari hasil pengamatan dianalisis ragam, bila terdapat perlakuan yang berbeda dilanjutkan dengan uji Duncan. Hasil penelitian menunjukkan penggunaan larutan kimia $\mathrm{KNO}_{3}$ dan $\mathrm{H}_{2} \mathrm{SO}_{4}$ mampu menunjukkan viabilitas benih kopi liberika yang baik.
\end{abstract}

Kata Kunci : dormansi, proses perkecambahan, dan daya kecambah 
Jurnal Media Pertanian Vol. 2 No. 2 Tahun 2017 Hal. 85 - 91

Media Komunikasi Hasil Penelitian dan Review Literatur Bidang Ilmu Agronomi

ISSN print $2503-1279$

ISSN online $2581-1606$

\section{PENDAHULUAN}

Kopi adalah salah satu komoditas unggulan dalam salah satu sub sektor perkebunan yang memiliki peluang pasar yang tinggi di dalam maupun di luar negeri dan mempunyai kontribusi cukup nyata dalam perekonomian Indonesia (Rahardjo, 2012). Provinsi Jambi memiliki berbagai jenis kopi yaitu Arabika, Robusta dan Liberika. Kopi jenis liberika merupakan tanaman kopi yang berasal dari Kabupaten Tanjung Jabung Barat dan telah ditetapkan sebagai varitas bina melalui Keputusan Menteri Pertanian Republik Indonesia No.4968/Kpts/SR.120/12/2013 tanggal 6 Desember 2013. Kopi liberika mampu beradaptasi baik di lahan gambut dengan tanaman penaung pinang. Kopi Liberika memiliki keunggulan yaitu daya adaptasinya yang baik di lahan gambut dan tahan terhadap serangan hama penyakit (Dirjen Perkebunan, 2014). Rata-rata potensi produksi kopi liberika adalah 909 gram kopi biji/pohon atau setara dengan $950 \mathrm{~kg}$ biji kopi untuk pemanenan dengan populasi 9001000 pohon/ha.

Berdasarkan data Statistik Dinas Perkebunan Kabupaten Tanjung Jabung Barat Tahun 2013 luas tanaman kopi liberika seluas 2.710 ha, terfokus di 5 Kecamatan yaitu Kecamatan Bram Itam, Betara, Kuala Betara, Pangabuan dan Senyerang.Pengembangan agribisnis komoditas kopi liberika di Kabupaten Tanjung Jabung Barat masih cukup terbuka, baik melalui program perluasan, intensifikasi untuk meningkatkan produktivitas, maupun perbaikan mutu dan pengembangan industri hilir.

Dalam praktek pembudidayaan kopi seringkali dihadapkan pada kendala biji yang mengalami dormansi, artinya mengalami masa istirahat atau tidak dapat berkecambah meskipun ditempatkan pada situasi yang ideal. Penyebab terjadinya dormansi biji kopi karena keadaan kulit biji yang keras sehingga air dan udara yang dibutuhkan dalam proses perkecambahan tidak dapat masuk dalam biji sehingga untuk berkecambah membutuhkan waktu yang cukup lama. Menurut Murniati dan Zuhry (2002), untuk mencapai stadium serdadu benih kopi (hipokotil tegak lurus) butuh waktu 4 - 6 minggu, sementara untuk mencapai stadium kepelan (membukanya kotiledon) membutuhkan waktu $8-12$ minggu keadaaan ini tentu akan berdampak pada penyediaan bibit. Untuk memaksimalkan perkecambahan benih kopi perlu adanya perlakuan sebelum penanaman. Perlakuan pada benih dapat dilakukan dengan berbagai cara antara lain dengan cara mekanis, fisik maupun kimia.

Pemecahan dormansi secara kimia dapat dilakukan dengan perendaman dalam asam kuat encer (skarifikasi kimia). Menurut Soetopo (1985), perlakuan menggunakan bahan kimia bertujuan agar kulit biji lebih mudah dimasuki air pada waktu proses imbibisi. Salah satu bahan kimia yang dapat digunakan adalah larutan $\mathrm{KNO}_{3}$. Hadipoetiyanti dan Luntungan (1988) menjelaskan bahwa larutan $\mathrm{KNO}_{3}$ pada konsentrasi $0,5 \%$ dapat effektif dalam meningkatkan permeabilitas kulit biji terhadap gas dan air. Menurut Hedty, Mukarlina dan Turnip (2014) perendaman benih kopi dalam larutan $\mathrm{H}_{2} \mathrm{SO}_{4}$ dengan konsentrasi $20 \%$ lebih cepat melunakkan kulit biji sehingga biji lebih mudah menyerap air yang dibutuhkan untuk imbibisi. Hasil penelitian (Suita dan Naning 2004) pada benih Tanjung (Mimusops elengi L) yang direndam dalam air kelapa selama 2 jam menghasilkan persentase kecepatan tumbuh dan persentase perkecambahan yang tinggi.

Perendaman benih dalam larutan air biasa juga mampu membantu mematahkan dormansi benih. Menurut Matsushima dan Sakagami (2013) dalam Pancaningtyas, Santoso dan Sudarianto (2014) perendaman benih merupakan salah satu metode 
Jurnal Media Pertanian Vol. 2 No. 2 Tahun 2017 Hal. 85 - 91

Media Komunikasi Hasil Penelitian dan Review Literatur Bidang Ilmu Agronomi

ISSN print $2503-1279$

ISSN online $2581-1606$

invigorasi untuk mempercepat tumbuhnya kecambah dan menghasilkan bibit yang vigor. Metode invigorasi melalui seed priming pada padi dapat meningkatkan kecepatan daya kecambah dan kecepatan pertumbuhan tunas

\section{METODE PENELITIAN}

Bahan-bahan yang digunakan dalam pelaksanaan penelitian ini adalah benih kopi jenis Liberika yang diambil dari kecamatan Betara Kebupaten Tanjung Jabung Barat, $\mathrm{KNO}_{3}, \mathrm{H}_{2} \mathrm{SO}_{4}$, Air biasa, Air Kelapa dan pasir. Sedangkan alat-alat yang digunakan dalam penelitian ini adalah handsprayer, gelas ukur, gelas piala, pengaduk, kertas, kotak perkecambahan, pisau silet/cutter, kukusan, kertas label dan alat tulis

Rancangan yang digunakan pada penelitian ini adalah Rancangan Acak Lengkap (RAL) dengan satu faktor yaitu perendaman benih kopi yang telah dibersihkan kulitnya menggunakan beberapa macam larutan $(\mathrm{L})$, sebagai berikut :

$\mathrm{L} 0=$ perendaman dengan $\operatorname{air}\left(\mathrm{H}_{2} \mathrm{O}\right)$

$\mathrm{L} 1=$ perendaman dengan $\mathrm{KNO}_{3}$ konsentrasi $0,5 \%$

$\mathrm{L} 2=$ perendaman dengan $\mathrm{H}_{2} \mathrm{SO}_{4}$ konsentrasi $20 \%$

L3 = perendaman dengan Air Kelapa konsentrasi 50\%

Setiap taraf perlakuan diulang 3 kali, sehingga terdapat 12 unit satuan percobaan, setiap satuan percobaan terdapat 40 benih, jadi jumlah keseluruhan benih yang dipakai sebanyak 480 benih kopi liberika.

\section{Pelaksanaan Penelitian`}

Media yang digunakan adalah pasir yang sudah diayak kemudian disterilkan dengan cara dikukus selama 1 jam, untuk mencegah timbulnya infeksi dari patogen terutama cendawan dumping off. Pasir dimasukkan kedalam tiap kotak perkecambahan (seed bed) yang telah disediakan dan diberi Furadan 3G. Benih kopi yang digunakan diambil dari pohon yang berproduksi tinggi dan bebas dari hama serta penyakit. Benih yang digunakan untuk persemaian adalah kopi Chery. Pengamatan yang dilakukan pada kopi chery dan beras yaitu dengan mengukur diameter biji, bobot tunggal biji kopi, warna kulit ari, jumlah benih dalam $1 \mathrm{~kg}$ dan warna kulit tanduk.

Kopi chery yang akan disemai kulit dan daging buahnya dibuang dengan tangan, tanpa merusak kulit tanduknya (endocarp). Lendirnya dibersihkan menggunakan abu gosok lalu dicuci dengan air sampai bersih dan dikeringkan selama 3 hari. Selanjutnya benih diseleksi dengan kriteria :ukuran seragam, tidak keriput dan benih dalam keadaan sehat atau tidak terserang hama penyakit. Perendaman benih kopi dilakukan sesuai perlakuan. Perendaman benih kopi dengan menggunakan larutan $\mathrm{KNO}_{3}$ pada konsentrasi $0,5 \%$ dan perlakuan perendaman dalam air biasa $\left(\mathrm{H}_{2} \mathrm{O}\right)$ dilakukan selama 24 jam. Perendaman benih dalam larutan $\mathrm{H}_{2} \mathrm{SO}_{4}$ dengan konsentrasi $20 \%$ selama 30 menit dan perendaman benih dalam air kelapa konsentrasi 50\% selama 4 jam. Selanjutnya benih-benih tersebut dibilas dengan air dan ditiriskan selanjutnya benih langsung disemaikan di bedengan dengan cara meletakkan bagian datar dari benih mengarah ke bawah dijejerkan dengan jarak 3 x $5 \mathrm{~cm}$, kemudian ditutup dengan lapisan pasir setebal $1 \mathrm{~cm}$. Parameter yang diamati; 1) Daya berkecambah benih merupakan peubah dari parameter viabilitas potensial yang menunjukkan kemampuan benih berkecambah, tumbuh dan berproduksi normal pada kondisi lingkungan optimal. Penentuan waktu perhitungan daya berkecambah dan peubah yang lainnya pada percobaan ini, didapatkan dari data pengamatan yang dimulai dari hari ke-2 sampai hari ke-60. 
Jurnal Media Pertanian Vol. 2 No. 2 Tahun 2017 Hal. 85 - 91

Media Komunikasi Hasil Penelitian dan Review Literatur Bidang Ilmu Agronomi

ISSN print $2503-1279$

ISSN online $2581-1606$

Rumus :
Daya Berkecambah $=$------------------------------- x 100\%
Jumlah benih yang dikecambahkan

2) Indeks Kecepatan Berkecambah. Indeks kecepatan perkecambahan adalah indeks yang menyatakan kecepatan munculnya kecambah setelah waktu tertentu. Indeks kecepatan perkecambahan dihitung mulai hari ke 2 setelah dikecambahkan selanjutnya setiap hari sampai akhir penelitian.

Rumus :

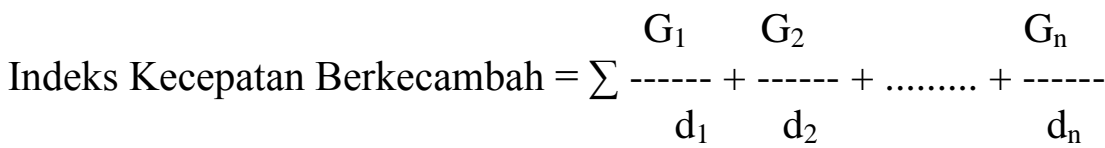

$\mathrm{G}=$ Jumlah benih berkecambah

$\mathrm{d}=$ Hari berkecambah

$\mathrm{n} \quad=\quad$ Hari ke-n

3) Tinggi Kecambah (cm). Pengukuran tinggi kecambah dilakukan pada akhir penelitian, dengan cara mengukur bagian antara kotiledon dan radikel. 4) Berat Kering Akar (mg).Pengukuran berat kering akar dilakukan dengan cara membersihkan akar kecambah dari tanah dan kotoran dengan menggunakan air. Akar dipotong dari pangkal batang kemudian dikeringkan dalam oven listrik pada suhu $80^{\circ} \mathrm{C}$ selama 2 hari, lalu ditimbang hingga diperoleh berat konstan. 5) Berat Kering Kecambah (mg). Penimbangan berat kering dilakukan pada akhir penelitian. Bibit kopi dibersihkan dari tanah dan kotoran menggunakan air selanjutnya dimasukkan ke dalam oven pada suhu $80^{\circ} \mathrm{C}$ selama 2 hari lalu ditimbang sampai diperoleh berat konstan. Data hasil percobaan dianalisis secara statistika dengan analisis ragam dan dilanjutkan dengan uji Duncan New Multiple Range Test (DNMRT) pada taraf $\alpha 5 \%$.

\section{HASIL DAN PEMBAHASAN}

Hasil analisis ragam secara umum menunjukkan bahwa perlakuan berpengaruh terhadap parameter daya kecambah, indeks kecepatan berkecambah, tinggi kecambah, berat kering kecambah dan berat kering akar. Penjelasan hasil pengamatan disajikan sebagai berikut:

Tabel 1. Pengaruh berbagai bahan kimia terhadap rerata daya kecambah, indeks kecepatan berkecambah, tinggi kecambah, berat kering kecambah dan berat kering akar

\begin{tabular}{|c|c|c|c|c|c|}
\hline \multirow[b]{2}{*}{ Bahan Kimia } & \multicolumn{5}{|l|}{ Parameter } \\
\hline & $\begin{array}{l}\text { Daya } \\
\text { Kecambah } \\
(\%)\end{array}$ & $\begin{array}{l}\text { Indeks } \\
\text { Kecepatan } \\
\text { Berkecambah }\end{array}$ & $\begin{array}{l}\text { Tinggi } \\
\text { Kecambah } \\
(\mathrm{cm})\end{array}$ & $\begin{array}{l}\text { Berat Kering } \\
\text { Kecambah } \\
(\mathrm{mg})\end{array}$ & $\begin{array}{l}\text { Berat } \\
\text { Kering } \\
\text { Akar (mg) }\end{array}$ \\
\hline Kontrol (L0) & $33.33 \mathrm{a}$ & $0,04 \mathrm{a}$ & $6.70 \mathrm{a}$ & $0,19 \mathrm{a}$ & $0,01 \mathrm{a}$ \\
\hline Air Kelapa (L3) & $41.67 \mathrm{a}$ & $0,05 \mathrm{~b}$ & $7.33 \mathrm{ab}$ & $0,22 a b$ & $0,02 \mathrm{ab}$ \\
\hline $\mathrm{KNO}_{3}$ (L1) & $58.33 \mathrm{a}$ & $0,06 \mathrm{bc}$ & $7.78 \mathrm{ab}$ & $0,27 \quad b$ & $0,03 \mathrm{~b}$ \\
\hline $\mathrm{H}_{2} \mathrm{SO}_{4}(\mathrm{~L} 2)$ & $58.33 \mathrm{a}$ & $0,07 \mathrm{c}$ & $8.30 \mathrm{~b}$ & $0,27 \quad b$ & $0,03 \mathrm{~b}$ \\
\hline
\end{tabular}

Keterangan: Angka-angka yang diikuti oleh huruf kecil yang sama berbeda tidak nyata menurut uji DNMRT taraf 95\% 
Jurnal Media Pertanian Vol. 2 No. 2 Tahun 2017 Hal. 85 - 91

Media Komunikasi Hasil Penelitian dan Review Literatur Bidang Ilmu Agronomi

ISSN print $2503-1279$

ISSN online $2581-1606$

Hasil uji lanjut DNMRT taraf $\alpha 5 \%$ menunjukkan bahwa perlakuan berbagai bahan kimia memberikan pengaruh yang berbeda tidak nyata terhadap daya kecambah, hal ini disebabkan karena data dalam ulangan sangat berbeda. Perlakuan pemberian $\mathrm{KNO}_{3}$ dan $\mathrm{H}_{2} \mathrm{SO}_{4}$ menunjukkan persentase daya kecambah yang tinggi dibandingkan kontrol dan air kelapa demikian juga dengan parameter indeks kecepatan berkecambah. Hal ini di duga karena terjadinya pelunakkan pada kulit biji. Menurut Schmidth (2002), pemberian $\mathrm{KNO}_{3}$ dan $\mathrm{H}_{2} \mathrm{SO}_{4}$ dapat meningkatkan kemampuan benih melakukan imbibisi. Selanjutnya (Kamil 1979) menyatakan bahwa penyerapan air oleh embrio dan endosperma menyebabkan pembesaran sel-sel pada embrio dan endosperma, sehingga mendesak kulit biji yang sudah lunak dan memberikan ruang untuk keluarnya tunas.

Menurut Sutopo (2004), bahwa perlakuan bahan kimia sering digunakan untuk memecahkan dormansi pada benih. Tujuannya adalah menjadikan agar kulit biji lebih mudah dimasuki oleh air pada waktu proses imbibisi. Gardner, dkk (1991) bahwa asam kuat sangat efektif untuk mematahkan dormansi pada biji yang memiliki struktur kulit keras, Asam sulfat $\left(\mathrm{H}_{2} \mathrm{SO}_{4}\right)$ sebagai asam kuat dapat melunakkan kulit biji sehingga dapat dilalui oleh air dengan mudah.

Larutan $\mathrm{KNO}_{3}$ merupakan larutan yang dapat berinteraksi dengan suhu dalam menstimulir perkecambahan benih. Bewley dan Black (1943) menyebutkan bahwa pematahan dormansi dengan $\mathrm{KNO}_{3}$ diduga berhubungan dengan aktifitas lintasan pentosa fosfat, ketersediaan $\mathrm{O}_{2}$ yang terbatas mengakibatkan lintasan pentosa fosfat menjadi nonaktif, karena $\mathrm{O}_{2}$ digunakan untuk aktifitas respirasi melalui lintasan lain.

Perlakuan $\mathrm{KNO}_{3}$ memberikan nilai tinggi kecambah yang lebih tinggi dari pada perlakuan kimia yang lainnya yaitu sebesar $8,30 \mathrm{~cm}$ dan perlakuan air kelapa memiliki nilai terendah, yaitu sebesar $6,70 \mathrm{~cm}$. Perlakuan larutan $\mathrm{KNO}_{3}$ memberikan hasil tinggi kecambah benih kopi liberika yang lebih tinggi daripada perlakuan lain, hal ini karena pada larutan tersebut kemampuan daya kecambah dan indeks kecepatan berkecambah juga lebih tinggi, sehingga benih kopi liberika berpeluang untuk tumbuh lebih tinggi. Hal ini disebabkan benih mengandung bahan makanan antara lain karbohidrat, protein, lemak dan mineral yang tersimpan dalam jaringan makanan (Sutopo, 2004). Komponen-komponen tersebut merupakan cadangan energi benih untuk pertumbuhannya, semakin besar energi yang dimiliki akan mendukung pertumbuhan tanaman yang lebih optimal.

Berat kering kecambah benih kopi liberika dengan pemberian larutan kimia $\mathrm{H}_{2} \mathrm{SO}_{4}$ dan larutan $\mathrm{KNO}_{3}$ menghasilkan nilai tertinggi yang sama yaitu $0,27 \mathrm{mg}$ sejalan dengan parameter persentase daya kecambah, indeks kecepatan berkecambah dan tinggi kecambah, dimana pada larutan kimia $\mathrm{KNO}_{3}$ dan $\mathrm{H}_{2} \mathrm{SO}_{4}$ memberikan nilai paling tinggi, sehingga dapat menunjang nilai berat kering kecambah.

Sejalan dengan parameter daya kecambah, indeks kecepatan berkecambah, tinggi kecambah, berat kering kecambah dan berat kering akar dapat dilihat bahwa perlakuan kontrol memiliki nilai paling rendah dibandingkan dengan perlakuan dengan menggunakan bahan kimia. Hal ini diduga karena kontrol tidak memiliki unsur-unsur atau larutan yang dapat membantu merangsang pertumbuhan terhadap semua parameter yang diamati. 
Jurnal Media Pertanian Vol. 2 No. 2 Tahun 2017 Hal. 85 - 91

Media Komunikasi Hasil Penelitian dan Review Literatur Bidang Ilmu Agronomi

ISSN print $2503-1279$ ISSN online $2581-1606$

\section{KESIMPULAN}

Penggunaan larutan kimia $\mathrm{KNO}_{3}$ dan $\mathrm{H}_{2} \mathrm{SO}_{4}$ dapat mematahkan dormansi benih kopi liberika dengan cara melunakkan kulit benih sedangkan penggunaan air biasa (kontrol) kurang mampu mematahkan dormansi benih kopi liberika.

\section{DAFTAR PUSTAKA}

Andrifah. 2012.Teknologi Benih. Http://Digilib.Unila.Ac.Id/768/9/BAB\%20II.Pdf. Diakses Pada Tanggal 21 April 2016.

Anonim. 2013. Teknik Pengujian Daya Kecambah Benih (Oryza Sativa) yang Diberi Perlakuan $\mathrm{KNO}_{3}$ 0,2 \% Dengan Metode Pkdp (Pada Kertas Gulung Dalam Pelastik). Http://Alhikmahcrew.Blogspot.Com. Diakses Tanggal 21 April 2016.

Anonim.2013. Kopi Liberika. Http://Stmj.Joko.Web.Id/Id1/1528-1424/KopiLiberika_104294_Stmj-Joko.Html. Diakses Pada Tanggal 09 Mei 2016.

Cahyanti, 2009. Pengaruh Perlakuan Pemecahan Dormansi Benih Pada Perkecambahan Kopi Arabika Klon USDA (Coffea Arabica L.). Universitas Brawijaya. Malang.

Copeland, L. O. 1976. Principles Of Seed Sciences And Technology. Burger Publishing Co, Minnesota.

Copeland, L. O. And Mcdonald, M. B. 2001. Principles Of Seed Science And Technology. Kluwer Academic Publisher. London. 467p.

Heddy, S. 1996. Hormon Tumbuhan. Raja Grafindo Persada. Jakarta.

Iskandar, J. 2014. Pengaruh Suhu Air Awal Dan Lama Perendaman Benih Terhadap Viabilitas Dan Vigor Benih Kopi Arabika (Coffea Arabica L.) Universitas Siliwangi. Tasikmalaya.

Kamil, J. 1982.Teknologi Benih I. Universitas Andalas, Padang.

Lukikariati, S, L.P Indriyani, Susilo Dan M.J Anwaruddinsyah. 1996. Pengaruh Naungan Konsentrasi Indo Butirat Terhadap Pertumbuhan Batang Bawah Manggis. Balai Penelitian Tanaman Buah Solok. Solok Dalam Jurnal Hortikultura. Vol. 6(3): 220-226.

Kuswanto, H. 1996. Dasar-Dasar Teknologi Produksi Dan Sertifikasi Benih. Penerbit Andi Yogyakarta.

Murniati, Dan E. Zuhry. 2002. Peranan Giberelin Terhadap Perkecambahan Benih Kopi Robusta Tanpa Kulit. Jurnal Sagu 1: 1-5.

Rahardjo, 2012. Panduan Budidaya Dan Pengolahan Kopi Arabika Dan Robusta.

Penebar Swadaya.Jakarta.

Rineksane, I.A. 2000. Perbanyakan Tanaman Manggis Secara In Vitro Dengan Perlakuan Kadar BAP, Air Kelapa Dan Arang Aktif. Tesis. Fakultas Pertanian. Universitas Gajah Mada.

Sadjad S, .1975. Proses Metabolisme Perkecambahan Benih Dalam Dasar-Dasar Teknologi Benih. Capita Selekta. Departemen Agronomi. Buku. Institut Pertanian Bogor. Bogor. $138 \mathrm{P}$.

Schmidth L. 2002. Pedoman Penanganan Benih Tanaman Hutan Tropis Dan Subtropis. Jakarta: Direktorat Jendral Rehabilitasi Lahan Dan Perhutanan Sosial Departemen Kehutanan.

Silomba, S, D, A. 2006. Pengaruh Lama Perendaman Dan Pemanasan Terhadap Viabilitas Benih Kelapa Sawit. Skripsi. Institut Pertanian Bogor. 
Jurnal Media Pertanian Vol. 2 No. 2 Tahun 2017 Hal. 85 - 91

Media Komunikasi Hasil Penelitian dan Review Literatur Bidang Ilmu Agronomi ISSN print $2503-1279$ ISSN online $2581-1606$

Silvia, L. 2014. Pengaruh Perendaman Benih Pada Berbagai Suhu Awal Air Terhadap Viabilitas Benih Kayu Afrika (Mmaesopsis Emini). Lampung.

Soemomarto. 1981, Perendaman Benih Kopi Robusta Dalam Larutan Zat Pengatur Tumbuh Giberelin (GA3). Medan.

Suita, E Dan Naning, Y. 2004. Pengaruh Perlakuan Pendahuluan Terhadap Daya Berkecambah Benih Kemiri (Aleurites Moluccana Wild.) Buletin Teknologi Perbenihan Balai Teknologi Perbenihan. Bogor.

Sutopo, L. 2004. Teknologi Benih. Buku. Rajawali Pres. Jakarta.

Widhityarini, D. Suryadi Mw, Purwantoro, A. 2011. Pematahan Dormansi Benih Tanjung Dengan Skarifikasi Dan Perendaman Kalium Nitrat.

Widyawati,N., Tohari, P. Yudono, Dan I. Soemardi. 2009. Permeabilitas Dan Perkecambahan Benih Aren (Arenga Pinnata (Wurmb) Merr). Jurnal Agronomi Indonesia 37 (2) : 152-158.

Winarni, T, B. 2009. Pengaruh Perlakuan Pendahuluan Dan Berat Benih Terhadap Perkecambahan Benih Kayu Afrika (Maesopsis Eminii Engl.). Skripsi. Fakultas Kehutanan. Institut Pertanian Bogor. 